Article type : Research article

\title{
From individuals to communities: how singleton invasive pine saplings lead to biodiversity change in the Brazilian Cerrado hotspot
}

Isolated pines restructure plant community

\section{Alessandra R. Kortz, Dalva M. Silva Matos \& Anne E. Magurran}

Kortz, A.R. (Corresponding author, ark4@st-andrews.ac.uk) ${ }^{1}$

Matos, D.M.S. (dmatos@ufscar.br)²

Magurran, A.E. (aem1@st-andrews.ac.uk)1

${ }^{1}$ Centre for Biological Diversity, School of Biology, University of St Andrews, Fife, KY16 9TH, United Kingdom, Email: ark4@st-andrews.ac.uk

2Departamento de Hidrologia, Universidade Federal de São Carlos (UFSCar), Washington Luís Highway, km 235 - SP-310, São Carlos (SP), Brazil

\section{Funding Information}

This work was funded by the Brazilian Ciência sem Fronteiras/Coordenação de Aperfeiçoamento de Pessoal de Nível Superior (CAPES) (1091/13-1), European Research Council (AdG BioTIME 250189and PoC BioCHANGE 727440), the Royal Society and the Brazilian Conselho Nacional de Desenvolvimento Científico e Tecnológico/CNPq (307839/2014-1).

\section{Abstract}

Questions: How do newly established species interact with existing assemblage members to alter local biodiversity? This question is especially topical given growing concerns about increased temporal turnover levels relative to background rates. Pine (Pinus spp.), a major invasive taxon in the southern hemisphere, is progressively dominating remaining fragments of the Brazilian savanna (Cerrado), a biodiversity hostpot. Because the Cerrado's diversity is linked to habitat heterogeneity we argue that the impact of these invasive singleton pines will be mediated by differences in local habitat structure. Here we use isolated invasive pines Pinus elliottii in the Cerrado as a study system to test the prediciton that changes in the diversity of native communities, in the presence of newly established exotic individuals, will be greatest in the dominant vegetation layer of a habitat.

This article has been accepted for publication and undergone full peer review but has not been through the copyediting, typesetting, pagination and proofreading process, which may lead to differences between this version and the Version of Record. Please cite this article as doi: $10.1111 /$ jvs. 12668

This article is protected by copyright. All rights reserved. 
Location: Itirapina Ecological Station, southeast of Brazil

Methods: We used a stratified random survey in $5 \times 5 \mathrm{~m}$ pairs of plots invaded by a single pine individual each matched by control uninvaded plots; both shrub and grass vegetation layers were sampled in both habitats. In total, 300 plots were sampled, 114 in the shrub-dominated campo sujo and 186 in the grass-dominated campo úmido.

Results: Over four hundred plant species were recorded. In both habitats, we detect marked shifts in species richness of the dominant vegetation layer. In line with our prediction, the nature of these changes is mediated by local habitat structure. We find significantly reduced species richness in the shrub layer of the shrub-dominated habitat but elevated species richness in the grass layer of the grass-dominated habitat in invaded sites ( $\mathrm{v}$. control). In the grass layer of campo úmido, pine initially decreases dominance thus allowing more species to colonize the plots.

Conclusions: The shape of the diversity v. establishment time relationship is layer dependent, with a significant relationship between dominance/evenness and pine size in the grass layer but no relationship in the shrub layer. Our results show that, though complex, the consequences for local biodiversity of non-native species establishment are not haphazard, and thus contribute to the understanding of species coexistence.

KEYWORDS: $\alpha$-diversity; biodiversity change; biological invasion; invasion impact; invasive species; community ecology; Cerrado; environmental heterogeneity; habitat structure; Pinus elliottii, species richness; vegetation layer

\section{Introduction}

A key question in ecology is how newly established species interact with existing assemblage members to alter local biodiversity. This question touches on fundamental issues such as the extent to which local communities are saturated with species, the impact that these new arrivals have on existing inhabitants, and the mechanisms that underpin coexistence. We know from recent research (Dornelas et al. 2014; Magurran et al. 2015) that assemblages worldwide are experiencing unprecedented levels of temporal turnover. Invasive species, thought to be a major contributor to this elevated turnover, are the subject of growing concern (Kolar \& Lodge 2001; Levine et al. 2003; Ortega \& Pearson 2005; Didham et al. 2007; Chytrý et al. 2008; Ehrenfeld 2010; Vilà et al. 2011; Simberloff et al. 2013; Qi et al. 2014; Dong et al. 2015; Carboni et al. 2016). As such, the quest to deepen understanding of the process by which new species become incorporated in existing assemblages is both topical and important.

We already know that invasive species drive biodiversity change (Simberloff et al. 2013; Dornelas et al. 2014), including biotic homogenization (Magurran et al. 2015), and lead to loss of function (Levine et al. 2003) and the loss of keystone species (Pyšek \& Richardson 2010). These changes are particularly dramatic when large populations of exotics have become established (Vilà et al. 2011; Qi et al. 2014). Parker et al. (1999) conceptualized that the impact caused by invasive species is a product of three of their attributes: the range size $R\left(\right.$ in $\left.\mathrm{m}^{2}\right)$, its average abundance per unit area (A, e.g. number of individuals per $\left.\mathrm{m}^{2}\right)$ and the effect per individual of the invader (E). Both range and abundance aspects of invasive species have been studied in relation to their impacts. For instance, extensive stands of invasive pine trees, for example, can dominate and reorganise communities (Richardson 2006). Even solitary individuals, such as those occurring on an invasion front, have the potential to change local biodiversity (Kolar \& Lodge 2001). However, impacts focused on the effect per individual of the invader remain poorly studied. Moreover, the mechanisms at play when invasive species initially establish are not well understood (Dong et al. 2015), yet it is the changes that occur at this point where management interventions may still be able to reverse impacts (Kolar \& Lodge 2001) as well as to determine if the new arrival is incorporated into the assemblage, and how it will impact the species already present there. A key challenge, therefore, is to understand how natural communities are restructured at this earliest phase of invasion.

This article is protected by copyright. All rights reserved. 
As MacArthur \& MacArthur (1961) predicted, habitat structure has an important role in mediating species establishment. Given the importance of structural complexity in promoting diversity, we argue that habitat structure may play a critical role in shaping the consequences, for ecological communities, of individuals at the vanguard of an invasion. This is because habitat structure mediates biotic interactions through niche availability and competition between individuals. Structurally complex habitats generally support more biological diversity than less complex ones (MacArthur \& MacArthur 1961). In addition, different types of structure favour different species. Thus, ecosystems composed of patchworks of structurally variable habitats will typically be more diverse than uniform ones.

Habitat structure - the vegetation structure of a habitat - has the potential to influence the establishment of new species in two ways. First, as is already clear, establishment probability can depend on habitat structure (e.g. Chytrý et al. 2008). For example, herbaceous vegetation is more likely to be invaded by alien species than broad-leaved deciduous woodlands (Chytrý et al. 2008). Second, given its role in shaping biotic interactions, habitat structure may mediate the interaction between invasive species, once established, and native taxa. Thus, the same propagule pressure could lead to markedly different outcomes for diversity, even over small geographic distances, if there is local variation in habitat structure. Because it is the repository of most biomass, we expect the dominant layer in a habitat to show the strongest response to invasion. Moreover, the link between habitat structure and diversity means that this response should be apparent from the earliest stages of invasion.

Given both the importance of biodiversity hotspots in maintaining global diversity and the lack of studies on biodiversity change attributed to invasive species, especially in lower latitudes, we decided to focus on the Cerrado (Brazilian savanna) as a study system. The Cerrado (see Supplementary Figure 1 online) is the second (after the Amazon) largest vegetation formation in South America, and originally extended across 2 million $\mathrm{km}^{2}$ (an area approximately the size of Western Europe) (Cardoso Da Silva \& Bates 2002). The Cerrado has the most diverse savanna flora in the world (Simon et al. 2009), with $>12,000$ species of plants, of which $35 \%$ are endemic (Zappi et al. 2015). Habitat heterogeneity underlies the Cerrado's diversity; different patches support distinct assemblages of species (Oliveira-Filho \& Ratter 2002). The Cerrado has a mosaic of habitat types, which are distinct in terms of vegetation structure and species composition. The greatest biomass in a Cerrado habitat is found in its dominant vegetation layer (Castro \& Kauffman 1998).

Newly established individuals, along an invasion front, provide a natural experiment allowing researchers to predict and quantify change in biodiversity. An advantage of the Cerrado system is access to two botanically distinct yet neighbouring habitats, which have been invaded over the same time scale, have experienced the same propagule pressure, and where there are no confounding effects of spatial or temporal scale. The two habitats are campo sujo (shrub-dominated) and campo úmido (grass-dominated). The habitats differ in hydric soil saturation, vegetation structure and species composition (Tannus \& Assis 2004). Campo sujo is an intermediate savanna type mostly located on quartzarenic neosol that primarily contains forbs, shrubs, occasional small trees and graminoids. Campo úmido is a wet grassland - a more open vegetation structure mostly located on gleysoil, which gets seasonally waterlogged and mostly contains graminoids, forbs and small shrubs (see also Figure 1) (Tannus \& Assis 2004; Zanchetta \& Diniz 2006).

Here we use isolated invasive pines Pinus elliottii in the Cerrado as a study system to test the hypothesis that the impact of newly established exotic individuals on the native communities is stronger in the dominant vegetation layer of a habitat. The understanding of the unfolding impacts of pine invasions in the Cerrado and other South American habitats is crucial as these invasions are recent and likely to expand substantially, as seen in other parts of the Southern Hemisphere (such as South Africa and New Zealand), with a much longer history of pine plantations (Richardson et al. 2008; Simberloff et al. 2010).

This article is protected by copyright. All rights reserved. 


\section{Methods}

\section{Data collection}

Fieldwork was carried out from November 2014 until April 2015 on the Cerrado vegetation of Itirapina Ecological Station, a legally protected area located between $22^{\circ} 11^{\prime}$ and $22^{\circ} 15^{\prime}$ south and $47^{\circ} 51^{\prime}$ and $47^{\circ} 57$ west in São Paulo state, Brazil (Figure S1). The study was focussed on a $7 \mathrm{~km}^{2}$ portion of the Station that pine seedlings are invading, and which mostly contains campo sujo and campo úmido habitats. Campo sujo has dry soil (quartzarenic neosol), and comprises mostly forbs, shrubs and small trees whereas campo úmido has waterlogged soil (gleysol), and more open vegetation structure comprised mostly by grasses and forbs (Figure 1) (Zanchetta \& Diniz 2006).

To quantify the biodiversity response as the invasive species establishes, and to elucidate the mechanisms that underpin local shifts in diversity in the immediate vicinity of the pine, we randomly selected isolated individual pine trees of any size and placed these at the centre of each 'invaded plot' measuring $5 \mathrm{~m} \times 5 \mathrm{~m}$. A corresponding 'control', non-invaded plot was placed $10 \mathrm{~m}$ away in a random direction - and at least $10 \mathrm{~m}$ distant from the nearest pine tree individual. This randomised design means that the control plots provide an unbiased assessment of the impact of the pine trees on assemblage diversity and structure as a whole. We sampled a total of 300 plots (invaded plus control), 186 in campo úmido and 114 in campo sujo. The height of each pine was recorded. Because most isolated pines are young, small individuals, the majority of sampled pine trees were $<5 \mathrm{~m}$ height; most of taller pine individuals were clustered. We expect $5 \mathrm{~m}$ tall pines to be approximately up to four years old (Coelho \& Finger 1997).

A considerable proportion of Cerrado diversity is found in the non-woody layer (namely herbaceous and graminoids species) (Felfili et al. 1994), usually overlooked in diversity studies. To test the prediction that habitat layer is important in mediating invasion impact we sampled vegetation in both layers in a plot, in both structurally distinct habitats. We used two methods to quantify plant abundance in each plot: 1) a count of all individual stems (small tree, palm tree, shrub, subshrub and forb) for the shrub layer and 2) a systematic survey to detect all species present in the grass layer (graminoids - grasses, sedges and rushes - and liana). The shrub layer thus includes any non-woody species (e.g. forbs), sampled by individual counts. To calculate diversity metrics for the grass layer we also sampled abundance data with a point quadrat - a non-destructive sampling method. Our point quadrat had 5 'pins'; we used the number of times a taxon was 'hit' by a pin as our measure of its numerical abundance (number of 'individuals') within the plot (Magurran 1988). The point quadrat was randomly placed 10 times in each plot - 50 'pins' per plot in total. Every plant individual in the shrub layer of each plot was therefore sampled, regardless of its size. All plants in each plot were identified to the best taxonomic resolution: species $(80.1 \%$ of individuals), genus $(12 \%)$, family $(7.2 \%)$ or morphospecies $(0.7 \%)$. All scientific names, authorities and families are in accordance with the Species List of the Brazilian Flora (Species List of the Brazilian Flora 2018).

\section{Statistical analyses}

Statistical analyses were conducted separately in the two habitats according to the sampling method used: count of individuals (abundance data, shrub layer) and all species present in a plot (incidence data, grass layer) or point quadrat (abundance data, grass layer). First, we evaluated species richness ( $\alpha$-diversity) using robust estimators to assess the impact of these isolated pine trees on the overall native Cerrado biodiversity at the assemblage level. To quantify the species richness ( $\alpha$ diversity) in each of the eight zones (invaded and control sites of campo sujo and campo úmido habitats for both shrub and grass layers) we employed the extrapolated rarefaction method using iNEXT package from R (R Core Team 2014; Hsieh et al. 2016). Extrapolated rarefaction generates a species accumulation curve as a function of either number of individuals (abundance data) or number of sampling units (incidence data); it is a robust and informative metric that allows ecologists to compare expected species richness between sites even when different total numbers of individuals

This article is protected by copyright. All rights reserved. 
have been sampled (Chao et al. 2014). Species richness is estimated relative to the maximum number of individuals (or sampling units) recorded in any of the conditions being compared (invaded vs control). In our study this maximum was 4176 and 8302 individuals in the shrub layer of campo sujo and campo úmido habitats, respectively. Species richness can be extrapolated to up to double the sampling units (or number of plots sampled) (Hsieh et al. 2016): 114 sampling units for campo sujo and 186 for campo úmido habitat. The extrapolated rarefaction method provides a 95\% confidence interval of expected species richness based on bootstrap (Chao et al. 2014; Hsieh et al. 2016).

Second, to test our hypothesis that the strongest response to invasion will be detected in the dominant vegetation layer in a system, we tested two null hypotheses that use the information provided by a rarefaction to compare assemblages: the ecological null hypothesis $\left(\mathrm{H}_{0 \mathrm{eco}}\right)$ and the biogeographical null hypothesis $\left(\mathrm{H}_{\text {obiog }}\right.$ ) (Cayuela et al. 2015). $\mathrm{H}_{0 \text { eco }}$ attests that two (or more) samples are drawn from the same underlying assemblage and as such share similar species richness, species composition and relative abundances (Cayuela et al. 2015). $H_{0 b i o g}$, however, assumes that while the samples have distinct species composition they share similar richness and relative abundance distributions (Cayuela et al. 2015). $\mathrm{H}_{0 \mathrm{eco}}$ and $\mathrm{H}_{0 \text { biog }}$ were tested using package rareNMtests from $\mathrm{R}(\mathrm{R}$ Core Team 2014).

Third, we calculated the species composition ( $\beta$-diversity) between invaded and control sites of the same habitat and layer using the robust Raup-Crick $\left(\beta_{\mathrm{RC}}\right)$ method (Chase et al. 2011). $\beta$ diversity links $\alpha$-diversity (local diversity) to $\gamma$-diversity (regional diversity Whittaker 1960). Observed differences in $\beta$-diversity could be due to chance as a result of the prevailing patterns in $\alpha$ and/or $Y$ diversity (Chase et al. 2011). Chase's $\beta_{\mathrm{RC}}$ makes it possible to determine where $\beta$-diversity differs from the null expectation, (the null being informed by local richness and by known $\gamma$-diversity - the complete list of species in each vegetation layer), on a scale from -1 to 1 . Values approaching 0 indicate no difference in the dissimilarity between sites compared to the null expectation; values approaching 1 indicate sites more dissimilar than expected and values approaching -1 indicate sites less dissimilar (more similar) than expected. This method is particularly robust for comparing species composition of areas with contrasting $\alpha$-diversity. $\beta_{\mathrm{RC}}$ analysis was conducted in the current vegan package of $R$ ( $R$ Core Team 2014) with the code provided by Chase et al (2011). Results were plotted using package corrplot from $R$ (R Core Team 2014).

Fourth, we focus on the plot level to determine whether changes in pine height are related to a shift in the dominance/evenness components of diversity, and hence community structure. Dominance and evenness metrics capture opposing aspects of the species abundance distribution and can be negatively correlated. We thus calculated two metrics, the Berger Parker index, a dominance index (Berger \& Parker 1970), and the PIE (Probability of Interspecific Encounter), an evenness index (Hurlbert 1971) The Berger-Parker index expresses the proportional abundance of the most abundant species (Berger \& Parker 1970), and it is calculated as:

$\mathrm{D}=\frac{N \max }{N}$ abundance.

where Nmax is the number of individuals in the most abundant species, and $\mathrm{N}$ is total

The PIE index represents the probability that two randomly chosen individuals in an assemblage represent two different species (Hurlbert 1971), it is robust to unequal sample size (Gotelli \& Ellison 2013), calculated as:

$\mathrm{PIE}=\frac{n}{(n-1)}\left(\begin{array}{c}1.0-\sum_{p i}^{s} 2 \\ i=1\end{array}\right)$

where $p_{i}$ is the proportion of the complete assemblage represented by species $i\left(p_{i}=N i N\right)$.

This article is protected by copyright. All rights reserved. 
The PIE and Berger Parker indices were calculated for each invaded plot, separately for both layers of the habitats.

We modelled pine height as a predictor of diversity in the invaded plots, using the 'two-lines' method (Simonsohn 2018). The two-lines method was chosen because it is regarded as the first valid method of detecting U-shaped relationships, given the extremely high false positive rates of quadratic regression tests (Simonsohn 2018). The two-lines method fits two separate regression lines to the data; Simonsohn (2018) argues that "a U-shape is present if the slopes are of opposite sign and are both statistically significant". In our case this represents one line for 'short' pine tree individuals and another for 'tall' pine tree individuals; the breakpoint between the lines is also calculated (Simonsohn 2018). The two-lines method was calculated using version v0.3 (available at http://webstimate.org/twolines/).

Finally, to ascertain whether there are consistent differences in species richness between corresponding pairs of invaded and control plots at the plot level, we used a Wilcoxon rank test using the wilcox function from $R$ ( $R$ Core Team 2014) to calculate the differences between observed species richness in corresponding pairs of invaded and control plots.

\section{Results}

\section{Overall biodiversity change at the assemblage level}

In line with our prediction, the presence of the invasive species was associated with marked changes in the dominant vegetation layer of each habitat: the shrub layer of campo sujo and the grass layer of campo úmido (Figure 1, Figures S2 \& S3). Species richness (measured by the extrapolated rarefaction) was significantly different between invaded and control sites in the dominant vegetation layer of each habitat. In invaded sites, compared to control, species richness was lower in the shrub layer of campo sujo but higher in the grass layer of campo úmido (Figure 1). No equivalent differences were detected in the sub-dominant vegetation of either habitat (Figure 1).

Both $\mathrm{H}_{0 \text { eco }}$ and $\mathrm{H}_{0 \text { biog }}$ null hypotheses were also rejected in the dominant layer of each habitat: the shrub layer of campo sujo and the grass layer of campo úmido (Figures S2 \& S3). This provides additional evidence that invaded and control sites (of the same habitat and layer) differ in species richness as well as species composition and relative abundances.

This article is protected by copyright. All rights reserved. 

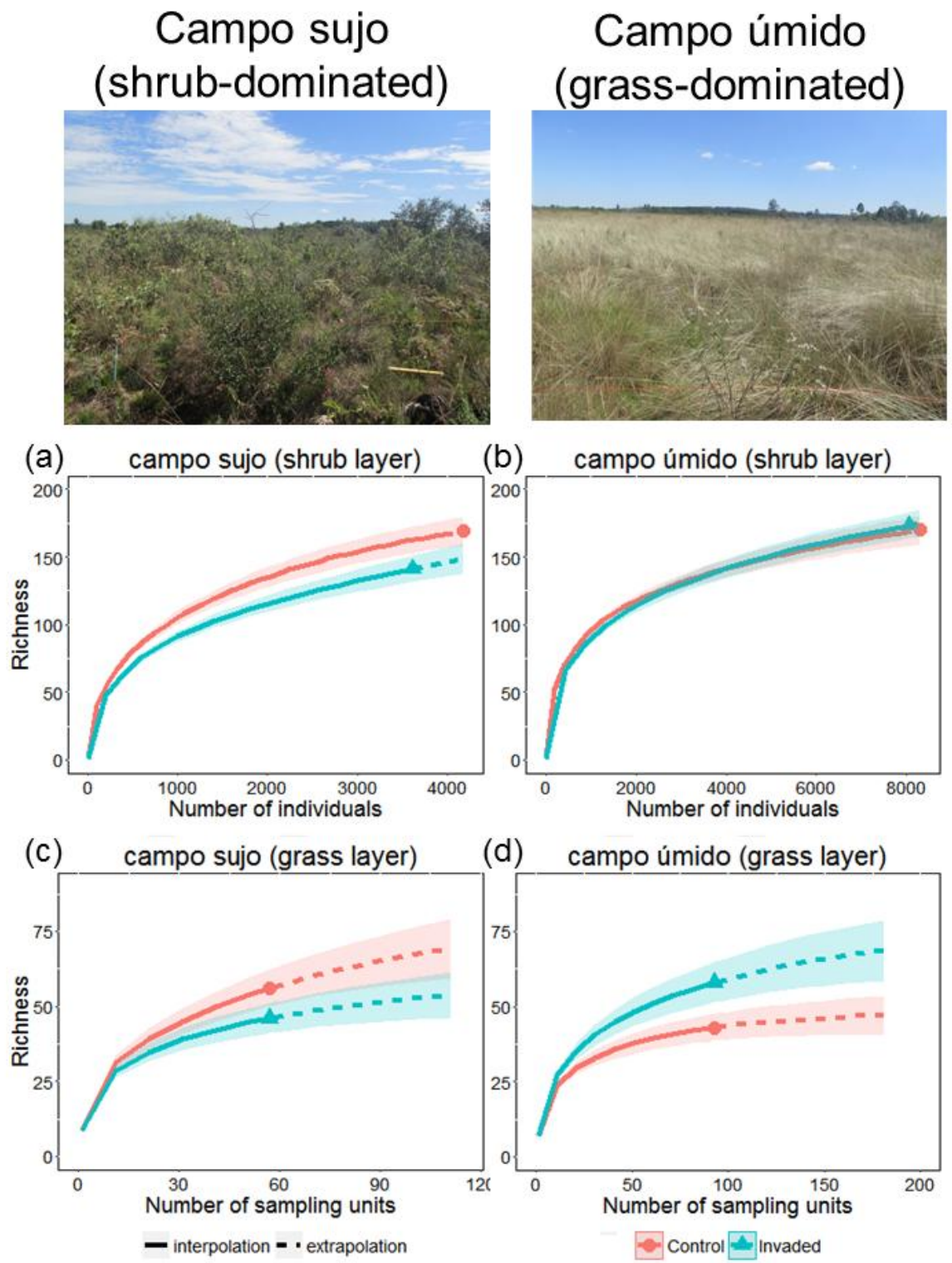

Figure 1. Extrapolated rarefaction curve calculated using iNEXT package (Hsieh et al. 2016) based on the number of individuals found in each largest sample in the shrub layer (abundance data), and the number of sampling units (plots) in the grass layer (incidence data) (values are in the main text). Species from both layers were sampled within each $5 \times 5 \mathrm{~m}$ plot. Solid lines represent the interpolation and dotted lines represent the extrapolation. The hatched area depicts the 95\% confidence interval. Species richness differed significantly between invaded and control plots in the dominant vegetation layer of each habitat in contrasting ways: in invaded sites species richness was (a) lower in the shrub layer of campo sujo and (d) higher in the grass layer of campo úmido habitat. Note difference in $\mathrm{x}$-axis scale between campo sujo and campo úmido graphs.

Taking all sampled species of each layer into account (total $\mathrm{y}$-diversity) Raup-Crick analysis revealed that species composition between invaded and control sites of the same habitat were more similar to one another than expected (Figure 2). There were, however, marked differences in species composition between the habitats in the shrub layer, as expected (Figure 2).

This article is protected by copyright. All rights reserved. 


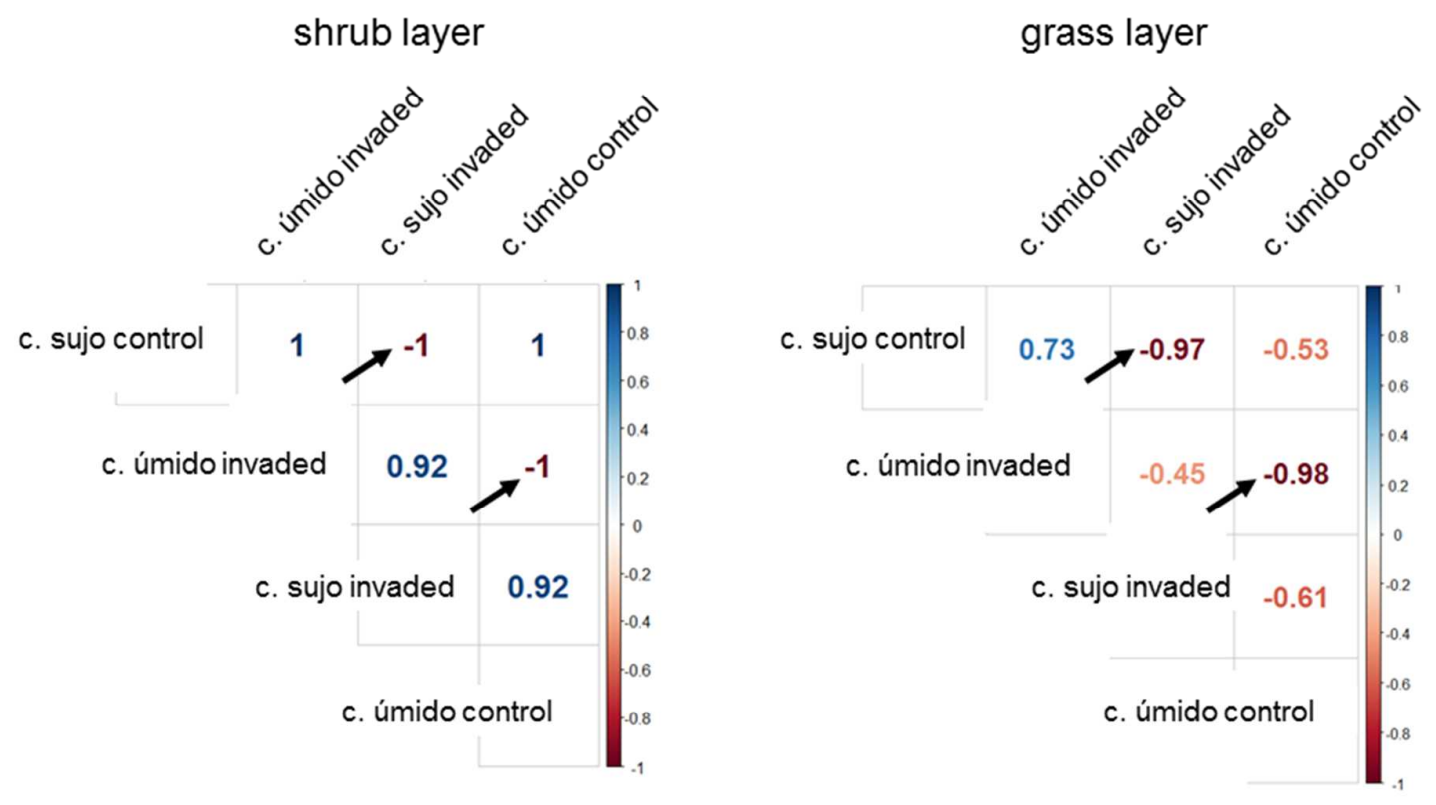

Figure 2. Correlogram plots of Raup-Crick dissimilarity results at the assemblage level. The Raup-Crick analysis was calculated with the code provided by (Chase et al. 2011) and the values were obtained using package corrplot from R. -1 represents habitats more similar in terms of species composition than expected by null models (red); 1 represents habitats less similar than expected by null models (blue) and 0 represents species composition no different than expected by null models (white). Arrows indicate the comparison of invaded v. control sites from the same habitat and layer which are more similar to one another than expected in all cases. Each vegetation layer was calculated separately.

\section{Quantifying biodiversity change after invasive pine establishment at the plot level}

As noted above, invaded sites, compared to control, had lower species richness in the shrub layer of campo sujo but higher species richness in the grass layer of the more open campo úmido. These results reflect assemblage level change (Figure 1). To understand the mechanistic basis of these patterns of change we turn to the plot level.

At the plot level, density plots showed no overall shifts in the number of individuals between invaded and control plots (Figure S4). This means that any changes we see are not linked to shifts in the numbers of individuals plots are supporting.

Pairwise comparison of observed richness between each pair of corresponding invaded and control plot in the shrub layer of the shrub-dominated campo sujo habitat revealed lower species richness in invaded plots than in their corresponding control ones (Figure S5). Species found only in control, and not in invaded plots, of campo sujo habitat include shrubs, subshrubs and a forb (Table S1). Taken together these results suggest that the presence of an isolated pine is associated with lower species richness in the shrub layer of campo sujo, regardless of pine size (Figure S6).

Our analysis of the grass layer of campo úmido revealed higher species richness in invaded sites, compared to control, at the assemblage level (Figure 1). In this habitat, at the plot level, we detected marked shifts in both dominance and evenness components of diversity as a function of pine height (Figure 3.b \& 3.d). We also found that, at intermediate heights of the pine, there was an initial decrease in dominance, mirrored by an increase in evenness (Figure 3). As pines grow larger, however, dominance increased and evenness decreased again - associated with lower species

This article is protected by copyright. All rights reserved. 
richness. Because most of the sampled pines were young, short individuals, this was reflected in increased overall diversity detected at the assemblage level.

A similar pattern was found in the grass layer of campo sujo, where there was an increase in dominance and a decrease in evenness detected for taller pines (second line only in Figure 3.a \& 3.c). Here, however, no initial decrease in dominance (and increase in evenness) was detected for short pines (Figure 3.a \& 3.c), hence no apparent increase in diversity was found. This is consistent with our observation of no difference in species richness between invaded and control sites at the assemblage level (Figure 1).

In the shrub layer, no significant relationship between pine height and dominance/evenness was found in any habitat (Figure S6).



Figure 3. Two-lines method applied for the invaded grass layer of both habitats for Berger Parker, a dominance index ( $a$ and $b$ ) and Probability of Interspecific Encounter (PIE), an evenness index ( $c$ and d) as related to invasive pine height. The two-lines method estimates a regression with two separate lines: one for "short" pine individuals and other for "taller" pine individuals, including a breakpoint to separate these (Simonsohn 2018). In campo sujo habitat there is an increase in dominance and a decrease in evenness for taller pines only (red line in a \& c). In campo úmido habitat (b \& d), all regression lines are significant for both Berger-Parker and PIE metrics.

Together with the shifts in dominance detected in the grass layer of the grass-dominated campo úmido (Figure 3), we also found that the identity of the most dominant species changed as pines grew larger (Figure 4.b). Here the change in dominance is reflected in the replacement of the most dominant species, Axonopus sp., by other species: Andropogon leucostachyus, Axonopus sp2, Trachypogon vestitus, Trachypogon sp., Loudetiopsis chrysothrix and Cyperus compressus (Figure 4.b). Additionally, species sampled in invaded, but not in control, sites within the grass-dominated

This article is protected by copyright. All rights reserved. 
habitat were also found in the shrub-dominated habitat, where they are more abundant. These species include sedges Cyperus sp., rushes Juncus densiflorus, grasses Imperata brasiliensis and lianas Serjania lethalis, Tynanthus micranthus. In contrast, in the campo sujo habitat although there was turnover in dominant species in relation to pine size there was less evidence of a clear substitution of dominant species (Figure 3.a).

Finally, because a U-shaped relationship was detected for the invaded grass layer of campo úmido habitat (Figure 3.b \& 3.c), we also modelled total abundance as a predictor of observed species richness in each invaded plot of this habitat to ascertain whether humped-shaped relationships could be explained by the 'more individuals hypothesis' (Evans et al. 2005), also using the two-lines method (Simonsohn 2018). Species richness did not increase monotonically with increased abundance in invaded grass layer of campo úmido (see Figure S7).



Figure 4. Proportion of the most dominant species in relation to pine height category in the invaded grass layer of campo sujo (a) and campo úmido (b) habitats. Circle size represents the proportion of invaded plots (in \%) in which species are dominant in each pine height category. The code to produce this Figure was adapted from (Zenni 2014). In invaded plots of campo úmido habitat (b) there was a reduction in the dominance of the most dominant species, Axonopus sp., thus allowing other species to establish and to become dominant in the plots.

Table 1. Summary of the main results. At the assemblage level, extrapolated rarefaction curves differ significantly in the dominant vegetation layer of each habitat: the shrub layer of campo sujo and the grass layer of campo úmido. In invaded sites, compared to control, there is lower species richness in the shrub layer of campo sujo whereas higher species richness was found in the grass layer of campo úmido. Both ecological null hypothesis and biogeographical null hypothesis were also rejected in the dominant vegetation layer of each habitat. At the plot level, lower species was also found in the shrub layer of campo sujo. In invaded plots, an initial decrease in dominance followed by an increase in dominance is observed as a function of pine height in the grass layer of campo úmido (this is mirrored by an initial increase in evenness followed by a decrease in evenness). In campo sujo habitat, also in

This article is protected by copyright. All rights reserved. 
the grass layer, only a later increase in dominance and a decrease in evenness were detected. * dominant vegetation layer. n.s. non-significant.

\begin{tabular}{|c|c|c|c|c|c|c|c|}
\hline & & \multicolumn{3}{|c|}{ assemblage level: invaded v. control sites } & \multicolumn{3}{|l|}{ plot level } \\
\hline Habitat & Layer & $\begin{array}{l}\text { Extrapolated } \\
\text { rarefaction } \\
\text { curves (Fig 1) }\end{array}$ & $\begin{array}{l}\mathrm{H}_{0 \text { eco }} \\
\text { (Figure S2) }\end{array}$ & $\begin{array}{l}\mathrm{H}_{\text {Obiog }} \\
\text { (Figure S3) }\end{array}$ & $\begin{array}{l}\text { differences in S } \\
\text { between } \\
\text { corresponding } \\
\text { pairs of invaded } \\
\text { and control plots } \\
\text { (Figure S5) }\end{array}$ & $\begin{array}{l}\text { shifts in } \\
\text { dominance } \\
\text { as as a } \\
\text { function of } \\
\text { pine height } \\
\text { (Fig 3) }\end{array}$ & $\begin{array}{l}\text { shifts in } \\
\text { evenness } \\
\text { as as a } \\
\text { function of } \\
\text { pine height } \\
\text { (Fig 3) }\end{array}$ \\
\hline $\begin{array}{l}\text { campo } \\
\text { sujo }\end{array}$ & shrub* $^{*}$ & invaded<control & rejected & rejected & invaded<control & n.s. & n.s. \\
\hline $\begin{array}{l}\text { campo } \\
\text { sujo }\end{array}$ & grass & indistinguishable & can't reject & rejected & n.s. & $\begin{array}{l}\text { late } \\
\text { increase in } \\
\text { dominance }\end{array}$ & $\begin{array}{l}\text { late } \\
\text { decrease in } \\
\text { evenness }\end{array}$ \\
\hline $\begin{array}{l}\text { campo } \\
\text { úmido }\end{array}$ & shrub & indistinguishable & can't reject & can't reject & n.s. & n.s. & n.s. \\
\hline $\begin{array}{l}\text { campo } \\
\text { úmido }\end{array}$ & grass* $^{*}$ & invaded $>$ control & rejected & rejected & n.s. & $\begin{array}{l}\text { initial } \\
\text { decrease in } \\
\text { dominance } \\
\text { then } \\
\text { increase in } \\
\text { dominance }\end{array}$ & $\begin{array}{l}\text { initial } \\
\text { increase in } \\
\text { evenness } \\
\text { then } \\
\text { decrease in } \\
\text { evenness }\end{array}$ \\
\hline
\end{tabular}

This article is protected by copyright. All rights reserved. 


\section{Discussion}

Our results provide compelling evidence that, in line with our prediction, the presence of singleton invasive pines can be associated with marked biodiversity change in the dominant vegetation layer (Figure 1). This conclusion is underpinned by the data collected at the plot level, indicating fine-scale effects, and by the extrapolated rarefaction suggesting overall assemblage responses. Invaded and control sites in the dominant vegetation layer of each habitat also differ in species richness, species composition and relative abundances (Figures S2 \& S3). In invaded sites, compared to control, there is lower species richness in the shrub layer of the shrub-dominated campo sujo but higher species richness of the grass-dominated campo úmido at the assemblage level (Figure 1). At the plot level, pairwise comparison of corresponding invaded and control plots also show lower species richness in the shrub layer of campo sujo, compared to control (Figure S5). The grass layer of campo úmido habitat, at the plot level, tended towards a segmented relationship between invader size and the dominance/evenness component of diversity (Figure $3 b \& 3 . d$ ). This is probably because the newly established pine individuals disrupt local dominance at intermediate heights, reducing dominance thus allowing more species to colonize. This reduction in dominance is short term, however, and dominance becomes more pronounced as the pine tree grows (Figure 3.b). Because most of the pine trees in our study were small these shifts translated into an overall increase in richness when viewed at the assemblage level (Figure 1).

Studies that experimentally plant invasive species in native areas and monitor changes in diversity over time are an ideal approach. This alternative is not feasible here, however, because this is a protected area where the plantation of invasive species is forbidden. Even if it was not forbidden, planting more invasive species in a highly invaded, and thus already threated, area would be unethical. As such, our sampling design, with randomised isolated pine tree individuals and corresponding control plots placed at a random direction (300 5x5m sampled plots in total), is the best means of evaluating invasive impacts on native assemblages.

\section{Habitat structure and biodiversity change}

Our study supports the idea that invasive pines can cause ecological impacts on native plant assemblages (Falleiros et al. 2011; Abreu \& Durigan 2011; Taylor et al. 2016; Nuñez et al. 2017). Crucially, we detected such changes at early stages of invasion marked by single invasive individuals. In the shrub layer of campo sujo, lower species richness in invaded areas was detected both at the assemblage (Figure 1) and at the plot level (Figure S5), whereas in the grass layer of the more open campo úmido pine initially disrupts dominance (Figures $3 \& 5$ ) thus leading to an apparent increased species richness at the assemblage level (Figure 1). In the grass layer of the shrub-dominated campo sujo, however, changes in the dominance/evenness components of diversity were detected for taller pine individuals only (Figure 3), and as such there was neither an initial decrease in dominance nor apparent increase in species richness. Therefore, species richness is indistinguishable between invaded and control areas in this subdominant layer (Figure 1).

Many studies testify to substantial negative impacts of pine trees by decreasing native species richness, particularly when they are established in high densities (e.g. Falleiros et al. 2011; Abreu \& Durigan 2011; Taylor et al. 2016; Nuñez et al. 2017). However, other investigations have found a positive relationship between diversity and pine invasion, for example associated with increased pine dominance in forest-dominated habitats (e.g. Taylor et al. 2016), in which more shaderesistant species are able to establish. By showing that vegetation layers (shrub and grass in our case) can respond differentially to the presence of invasive pine trees, and that this response can change as saplings grow larger, our results help resolve the paradox of the inconsistent impact of these trees on local biodiversity.

Even though marked changes in species richness ( $\alpha$ diversity) were found in the dominant vegetation layer of each habitat, $\beta_{\mathrm{RC}}$ analysis showed that species composition ( $\beta$ diversity) between

This article is protected by copyright. All rights reserved. 
invaded and control sites (of the same habitat and layer) is similar (Figure 2). As expected, the two habitats have, however, distinct species composition, crucially in the shrub layer (Figure 2). This suggests that the invasion time has not been sufficient yet to lead to overall changes in species composition at this early stage of invasion, in line with other evidence (Taylor et al. 2016).

\section{Patterns of biodiversity change and potential mechanisms}

The different outcomes for biodiversity in the two habitats highlight the different mechanisms at play. Our results suggest that the degree of dominance is a key factor (Hillebrand et al. 2008). Rises in dominance in ecological communities are almost invariably associated with a reduction in evenness (Stirling \& Wilsey 2001; Caldeira et al. 2005; Hillebrand et al. 2008). This is because conditions that favour one species, and enable it to pre-empt more of a resource, such as space, may reduce the competitive ability of other taxa. A classic example is increased productivity. For example, in the Park Grass experiment, additions of fertilizer enabled certain grass species to become dominants. As productivity rose, so too did dominance - rises that were matched by falls in richness and evenness (Tilman 1982). This link between diversity and productivity has led to the proposal that humped diversity curves, including those reported as evidence for the intermediate disturbance hypothesis might be most parsimoniously explained by a response to an increase in abundance.

In our study we observed a marked pattern of changes in evenness and dominance in the grass layer of both habitats. One explanation for this pattern, therefore, is the 'more individuals hypothesis', which predicts that species richness increases monotonically with density (Evans et al. 2005). We found no evidence for a monotonic relationship between species richness and abundance in invaded grass layer of campo úmido, though we did observe U-shaped one (see Supplementary Figure S7 online). This suggests little support for 'more individuals hypothesis' (Evans et al. 2005) - a finding in line with other recent studies (e.g. (Tilman et al. 2001; McGlynn et al. 2010). Instead it points towards changing dominance as the main mechanism. As such we suggest that in the early stages of establishment the pine saplings disrupt local dominants through physical changes to the environment such as pre-emption of nutrients and moisture. Once these impacts reach a certain threshold they again favour a subset of species that can cope with the changed habitat. These taxa (e.g. Andropogon leucostachyus, Axonopus sp2, Trachypogon vestitus, Trachypogon sp., Loudetiopsis chrysothrix and Cyperus compressus) then begin to dominate. We note that the finding we report is a correlational one, and that experimental tests will be needed to confirm the potential mechanisms discussed here.

\section{Implications for understanding biodiversity change}

There can be no doubt that 'wild nature' is under grave threat due to a combination of anthropogenic impacts. Although much of the focus has been of biodiversity loss, it is now apparent that biodiversity change is a pervasive problem (Dornelas 2010; McGill et al. 2014; Dornelas et al. 2014; Magurran et al. 2015; Young et al. 2016; Vellend et al. 2017). Invasive species are a major driver of this biodiversity change yet is clear from the literature that there is no single biodiversity response to their presence. For example, a meta-analysis on invasive plant species reported a reduction in diversity in $69 / 136$ cases, suggesting that the relationship between invasion and biodiversity is not straightforward (Vilà et al. 2011). Vilà et al. also stressed that both the magnitude and the direction of impacts depend on the ecological complexity of the communities. Another review of over 150 studies on the mechanisms of invasive species' impacts revealed that although the majority report changes in community structure they typically do not identify the mechanism by which invasion impacts biodiversity (Levine et al. 2003). In part this is because studies report pattern rather than process.

As we have shown, the consequences, for assemblage diversity, of invasions depend on many factors including habitat structure, time of invasion (quantified as size of the invader), and local diversity of a system. We detected marked biodiversity change but with the direction and nature of change linked to both the relative size of the invasive and the local habitat structure. These context-

This article is protected by copyright. All rights reserved. 
dependent and nuanced results are consistent with and can help account for the varying conclusions reported in the literature (as in Didham et al. 2007; Vilà et al. 2011; Dong et al. 2015). Our results nonetheless show that, though complex, the consequences for local biodiversity of species establishment are not haphazard. In particular they highlight the need to take account of habitat structure when predicting the changes in biodiversity that will ensue as a result of species colonisations. As such they contribute to the understanding of species coexistence and help explain why species invasion can lead to very different biodiversity outcomes.

\section{Acknowledgements}

We thank: the Forestry Institute in Brazil, Denise Zanchetta and Helena D. Lutgens for permission to conduct fieldwork in the area; Eric Y. Kataoka, Ana Carolina D. Castello and Rafael O. Xavier for valuable help with species identification; Luis A. Joaquim for fieldwork assistance; Maria João Janeiro for helpful suggestions for the manuscript and the Programa de Pós Graduação em Ecologia e Recursos Naturais from the Universidade Federal de São Carlos for logistic support. ARK thanks Ciência sem Fronteiras/CAPES for a fully funded PhD fellowship at the University of St Andrews.

\section{Data accessibility}

To be included. If the paper is accepted for publication, a one-year period embargo will be requested. The data will be published as Research data at the University of St Andrews where they will be assigned a DOI.

\section{References}

Abreu, R.C.R., \& Durigan, G. 2011. Changes in the plant community of a Brazilian grassland savannah after 22 years of invasion by Pinus elliottii Engelm. Plant Ecology \& Diversity 4: 269278.

Berger, W.H., \& Parker, F.L. 1970. Diversity of planktonic foraminifera in deep-sea sediments. Science 168: 1345-1347.

Caldeira, M.C., Hector, A., Loreau, M., \& Pereira, J.S. 2005. Species richness, temporal variability and resistance of biomass production in a Mediterranean grassland. Oikos 110: 115-123.

Carboni, M., Münkemüller, T., Lavergne, S., Choler, P., Borgy, B., Violle, C., Essl, F., Roquet, C., Munoz, F., \& Thuiller, W. 2016. What it takes to invade grassland ecosystems: Traits, introduction history and filtering processes. Ecology Letters 19: 219-229.

Cardoso Da Silva, J.M., \& Bates, J.M. 2002. Biogeographic Patterns and Conservation in the South American Cerrado: A Tropical Savanna Hotspot. BioScience 343: 225.

Castro, E.A., \& Kauffman, J.B. 1998. Ecosystem Structure in the Brazilian Cerrado : A Vegetation Gradient of Aboveground Biomass, Root Mass and Consumption by Fire. Journal of Tropical Ecology 14: 263-283.

Cayuela, L., Gotelli, N.J., \& Colwell, R.K. 2015. Ecological and biogeographic null hypotheses for comparing rarefaction curves. Ecological Monographs 85: 437-455.

Chao, A., Gotelli, N.J., Hsieh, T.C., Sander, E.L., Ma, K.H., Colwell, R.K., \& Ellison, A.M. 2014. Rarefaction and extrapolation with Hill numbers: A framework for sampling and estimation in species diversity studies. Ecological Monographs 84: 45-67.

Chase, J.M., Kraft, N.J.B., Smith, K.G., Vellend, M., \& Inouye, B.D. 2011. Using null models to disentangle variation in community dissimilarity from variation in $\alpha$-diversity. Ecosphere 2: 1-11.

This article is protected by copyright. All rights reserved. 
Chytrý, M., Jarosik, V., Pysek, P., Hájek, O., Knollová, I., Tichý, L., \& Danihelka, J. 2008. Separating habitat invasibility by alien plants from the actual level of invasion. Ecology 89: 1541-1553.

Coelho, M.C.B., \& Finger, C.A.G. 1997. Crescimento em altura para Pinus elliottii Engelm. originado por diferentes métodos de regeneração em Canela, RS [Growth height for Pinus elliottii Engelm originated from different regeneration methods in Canela, RS]. Ciência Florestal 7: 139-155.

Didham, R.K., Tylianakis, J.M., Gemmell, N.J., Rand, T.A., \& Ewers, R.M. 2007. Interactive effects of habitat modification and species invasion on native species decline. Trends in Ecology and Evolution 22: 489-496.

Dong, L.-J., Yu, H.-W., \& He, W.-M. 2015. What determines positive, neutral, and negative impacts of Solidago canadensis invasion on native plant species richness? Scientific Reports 5: 16804.

Dornelas, M. 2010. Disturbance and change in biodiversity. Philosophical transactions of the Royal Society of London. Series B, Biological sciences 365: 3719-27.

Dornelas, M., Gotelli, N.J., McGill, B., Shimadzu, H., Moyes, F., Sievers, C., \& Magurran, A.E. 2014. Assemblage time series reveal biodiversity change but not systematic loss. Science 344: 296-9.

Ehrenfeld, J.G. 2010. Ecosystem Consequences of Biological Invasions. Annual Review of Ecology, Evolution, and Systematics 41: 59-80.

Evans, K.L., Greenwood, J.J.D., \& Gaston, K.J. 2005. Dissecting the species-energy relationship. Proceedings of the Royal Society B-Biological Sciences 272: 2155-2163.

Falleiros, R.M., Zenni, R.D., \& Ziller, S.R. 2011. Invasão e manejo de Pinus taeda em campos de altitude do Parque Estadual do Pico Paraná, Paraná, Brasil [Invasion and managment of Pinus taeda in mountain top grasslands of Pico Parana State Park, Parana, Brazil]. Floresta 41: 123134.

Felfili, J.M., Filgueiras, T.S., Haridasan, M., Mendonça, R., \& Rezende, A.V. 1994. Projeto biogeografia do bioma cerrado: Vegetação e solos [Biogeography of the Cerrado Biome Project: vegetation and soil].

Gotelli, N.J., \& Ellison, A.M. 2013. A primer of ecological statistics. Sinauer associates, Massachusetts.

Hillebrand, H., Bennett, D.M., \& Cadotte, M.W. 2008. Consequences of dominance: a review of evenness effects on local and regional ecosystem processes. Ecology 89: 1510-1520.

Hsieh, T.C., Ma, K.H., \& Chao, A. 2016. iNEXT: An R package for rarefaction and extrapolation of species diversity (Hill numbers). Methods in Ecology and Evolution. doi: 10.1111/2041210X.12613

Hurlbert, S.H. 1971. The non concept of species diversity: A critique and alternative parameters. Ecology 52: 577-585.

Kolar, C.S., \& Lodge, D.M. 2001. Progress in invasion biology: predicting invaders. Trends in ecology \& evolution 16: 199-204.

Levine, J.M., Vilà, M., D’Antonio, C.M., Dukes, J.S., Grigulis, K., \& Lavorel, S. 2003. Mechanisms underlying the impacts of exotic plant invasions. Proceedings of the Royal Society B: Biological Sciences 270: 775-781.

MacArthur, R.H., \& MacArthur, J.W. 1961. On Bird Species Diversity. Ecology 42: 594-598.

This article is protected by copyright. All rights reserved. 
Magurran, A.E. 1988. Ecological diversity and its measurement. Princeton University Press, Princeton.

Magurran, A.E., Dornelas, M., Moyes, F., Gotelli, N.J., \& McGill, B. 2015. Rapid biotic homogenization of marine fish assemblages. Nature Communications 6: 8405 .

McGill, B.J., Dornelas, M., Gotelli, N.J., \& Magurran, A.E. 2014. Fifteen forms of biodiversity trend in the Anthropocene. Trends in Ecology \& Evolution 30: 104-113.

McGlynn, T.P., Weiser, M.D., \& Dunn, R.R. 2010. More individuals but fewer species: testing the "more individuals hypothesis" in a diverse tropical fauna. Biology letters 6: 490-493.

Nuñez, M.A., Chiuffo, M., Torres, A., Paul, T., Dimarco, R.D., Raal, P., Policelli, N., Moyano, J., García, R.A., van Wilgen, B.W., Pauchard, A., \& Richardson, D.M. 2017. Ecology and management of invasive Pinaceae around the world : progress and challenges Ecology and management of invasive Pinaceae around the world : progress and challenges. Biological Invasions 19: 3099-3120.

Oliveira-Filho, A., \& Ratter, J.A. 2002. Vegetation physiognomies and woody flora of the cerrado biome. In Oliveira, P.S. \& Marquis, R.J. (eds.), The Cerrados of Brazil: Ecology and natural history of a neotropical savanna, pp. 91-119. Columbia University Press, New York.

Ortega, Y.K., \& Pearson, D.E. 2005. Weak vs . Strong Invaders of Natural Plant Communities: Assessing Invasibility and Impact. Ecological Applications 15: 651-661.

Parker, I.M., Simberloff, D., Lonsdale, W.M., Goodell, K., Wonham, M., Kareiva, P.M., Williamson, M.H., Von Holle, B., Moyle, P.B., Byers, J.E., \& Goldwasser, L. 1999. Impact: toward a framework for understanding the ecological effects of invader. Biological Invasions 1: 3-19.

Pyšek, P., \& Richardson, D.M. 2010. Invasive Species, Environmental Change and Management, and Health. Annual Review of Environment and Resources 35: 25-55.

Qi, S.-S., Dai, Z.-C., Zhai, D.-L., Chen, S.-C., Si, C.-C., Huang, P., Wang, R.-P., Zhong, Q.-X., \& Du, D.-L. 2014. Curvilinear Effects of Invasive Plants on Plant Diversity: Plant Community Invaded by Sphagneticola trilobata. PLOS ONE 9: e113964.

R Core Team. 2014. R: A language and environment for statistical computing.

Richardson, D.M. 2006. Pinus: a model group for unlocking the secrets of alien plant invasions? Preslia 78: 375-388.

Richardson, D.M., Wilgen, B.W., \& Nuñez, M. a. 2008. Alien conifer invasions in South America: short fuse burning? Biological Invasions 10: 573-577.

Simberloff, D., Martin, J.L., Genovesi, P., Maris, V., Wardle, D.A., Aronson, J., Courchamp, F., Galil, B., García-Berthou, E., Pascal, M., Pyšek, P., Sousa, R., Tabacchi, E., \& Vilà, M. 2013. Impacts of biological invasions: What's what and the way forward. Trends in Ecology and Evolution 28: 58-66.

Simberloff, D., Nuñez, M. a., Ledgard, N.J., Pauchard, A., Richardson, D.M., Sarasola, M., Van Wilgen, B.W., Zalba, S.M., Zenni, R.D., Bustamante, R., Peña, E., \& Ziller, S.R. 2010. Spread and impact of introduced conifers in South America: Lessons from other southern hemisphere regions. Austral Ecology 35: 489-504.

Simon, M.F., Grether, R., de Queiroz, L.P., Skema, C., Pennington, R.T., \& Hughes, C.E. 2009. Recent assembly of the Cerrado, a neotropical plant diversity hotspot, by in situ evolution of

This article is protected by copyright. All rights reserved. 
adaptations to fire. Proceedings of the National Academy of Sciences of the United States of America 106: 20359-20364.

Simonsohn, U. 2018. Two-Lines: A Valid Alternative to the Invalid Testing of U-Shaped Relationships with Quadratic Regressions. SSRN. doi: http://dx.doi.org/10.2139/ssrn.3021690

Species List of the Brazilian Flora. 2018. Lista de espécies da flora do Brasil. Jardim Botânico do Rio de Janeiro.

Stirling, G., \& Wilsey, B. 2001. Empirical Relationships between Species Richness, Evenness, and Proportional Diversity. The American naturalist 158: 286-299.

Tannus, J.L.S., \& Assis, M.A. 2004. Composição de espécies vasculares de campo sujo e campo úmido em área de cerrado, Itirapina - SP, Brasil [Vascular species composition of dry and swamp grasslands in a savanna area, Itirapina - SP, Brazil]. Revista Brasileira de Botânica 27: 489-506.

Taylor, K.T., Maxwell, B.D., Pauchard, A., Nuñez, M.A., \& Rew, L.J. 2016. Native versus non-native invasions: similarities and differences in the biodiversity impacts of Pinus contorta in introduced and native ranges. Diversity and Distributions 22: 1-11.

Tilman, D. 1982. Resource competition and community structure. Princeton Univeristy Press, New Jersey.

Tilman, D., Reich, P.B., Knops, J., Wedin, D., Mielke, T., \& Lehman, C. 2001. Diversity and productivity in a long-term grassland experiment. Science 294: 843-5.

Vellend, M., Dornelas, M., Baeten, L., Beausejour, R., Brown, C., De Frenne, P., Elmendorf, S., Gotelli, N., Moyes, F., Myers-Smith, I., Magurran, A., McGill, B., Shimadzu, H., \& Sievers, C. 2017. Estimates of local biodiversity change over time stand up to scrutiny. Ecology 0: 1-8.

Vilà, M., Espinar, J.L., Hejda, M., Hulme, P.E., Jarošík, V., Maron, J.L., Pergl, J., Schaffner, U., Sun, Y., \& Pyšek, P. 2011. Ecological impacts of invasive alien plants: a meta-analysis of their effects on species, communities and ecosystems. Ecology Letters 14: 702-708.

Whittaker, R. 1960. Vegetation of the Siskyiou mountains, Oregon and California. Ecological Monographs 30: 279-338.

Young, H.S., Parker, I.M., Gilbert, G.S., Sofia Guerra, A., \& Nunn, C.L. 2016. Introduced Species, Disease Ecology, and Biodiversity-Disease Relationships. Trends in Ecology \& Evolution 32: 114.

Zanchetta, D., \& Diniz, F.V. 2006. Estudo da contaminação biológica por Pinus spp. em três diferentes áreas na Estação Ecológica de Itirapina (SP, Brasil) [Study of the biological invasion by Pinus spp. in three different areas of Itirapina Ecological Station (Brazil)]. Revista do Instituto Florestal 18: 1-14.

Zappi, D.C., Ranzato Filardi, F.L., Leitman, P., Souza, V.C., Walter, B.M.T., Pirani, J.R., Morim, M.P., Queiroz, L.P., Cavalcanti, T.B., Mansano, V.F., \& Forzza, R.C. 2015. Growing knowledge: An overview of Seed Plant diversity in Brazil. Rodriguesia 66: 1085-1113.

Zenni, R.D. 2014. Analysis of introduction history of invasive plants in Brazil reveals patterns of association between biogeographical origin and reason for introduction. Austral Ecology 39: 401-407.

SUPPORTING INFORMATION

This article is protected by copyright. All rights reserved. 
Additional Supporting Information may be found online in the supporting information tab for this article.

Appendix S1. Seven supplementary figures referred to in the text.

Figure S1. (a) Cerrado (Brazilian savanna) distribution (in grey) in Brazil (thicker line) and (b) sampling locations in both patchily distributed Cerrado habitats: shrub-dominated campo sujo and grass-dominated campo úmido.

Figure S2. Ecological null model test with randomization tests comparing rarefaction curves of invaded and control sites of each habitat (campo sujo and campo úmido) and vegetation layer (shrub and grass).

Figure S3. Biogeographical null model test with randomization tests comparing rarefaction curves of invaded and control sites of each habitat (campo sujo and campo úmido) and vegetation layer (shrub and grass).

Figure S4. Density plots considering total abundance per plot in invaded and control sites in both habitats and layers.

Figure S5. Paired plot comparison of the differences in observed number of species between correspondent pairs of invaded and control plots.

Figure S6. Two-lines method applied for the invaded shrub layer of both habitats for Berger Parker, a dominance index and Probability of Interspecific Encounter (PIE), an evenness index as related to invasive pine height.

Figure S7. Two-line results for the grass layer of invaded plots of campo úmido habitat considering observed richness per plot as a predictor of total abundance per plot (quantified with the point quadrat).

Table S1. Species not present in invaded, only in control, sites of the shrub-dominated habitat (campo sujo).

This article is protected by copyright. All rights reserved. 